\title{
A proposed global boundary stratotype for the base of the Upper Series of the Ordovician System: The Fågelsång section, Scania, southern Sweden
}

\author{
1 Department of Geological Sciences, The Ohio State University, Columbus, OH 43210, USA \\ 2 Department of Geological Sciences, California State University at Long Beach, Long Beach, CA 90840, USA \\ 3 Nanjing Institute of Geology and Palaeontology, 39 Beijing Road, Nanjing 210008, China \\ 4 Department of Geology, Lund University, Sölvegatan 13, Se-22362 Lund, Sweden \\ 5 Universidade do Estado do Rio de Janeiro, Faculdade de Geologia, Rua Sao San Francisco Xavier 524, 20559-900 Rio de Janeiro, Brazil
}

A world-wide search for stratigraphic sections exposing the base of the Nemagraptus gracilis Biozone, the level selected to define the base of the global Upper Ordovician Series, resulted in the recognition of three potential boundary stratotypes, namely the Fågelsång, Calera, and Dawangou sections, all of which have been restudied during the last four years. These sections fulfill most of the requirements for a GSSP, and their biozone boundaries can be correlated precisely with each other. Based on an assessment of all information now available, it is concluded that the Fågelsång section is slightly superior to the others as a global boundary stratotype. It has excellent and well-known graptolite and conodont biostratigraphy in a stratigraphically continuous succession of uniform lithology, is readily accessible, and the key interval is not affected by faulting. The boundary interval is exposed in two natural outcrops that have not changed substantially for more than a century, and the same interval is also present in two drill-cores from the Fågelsång region. Although having some drawbacks, the Calera and Dawangou boundary sections are likewise excellent in most significant respects and they are proposed to be selected as auxiliary stratotypes.

\section{Introduction}

Since 1989, several working groups of the International Subcommission on Ordovician Stratigraphy (ISOS) of the International Commission on Stratigraphy (ICS) have been involved in an very extensive project with the goal of establishing a scheme of globally applicable stage and series subdivisions of the Ordovician System (Webby, 1994). Previously used Ordovician major chronostratigraphic subdivisions have been of provincial character and mostly based on endemic fossils, making global correlations difficult and uncertain. This is well illustrated by the fact that, for instance, the term Upper Ordovician has had a vastly different scope as used in North America, Australia, Baltoscandia, China, and United Kingdom (Webby, 1998, figure 1), and even within some of these regions, this term has not been uniformly defined. This has led to confusion, especially among non-stratigraphers, and there is clearly a need to standardize the international series and stage terminology following the recent practice adopted for other systems. The working groups have made considerable progress and two Ordovician chronostratigraphic units, the Darriwilian and Tremadocian Stages, have thus far been formally ratified by the ICS as a global stage terms (Mitchell et al., 1997). Several biostratigraphically defined horizons (Figure 1) have been approved by the ISOS as suitable global series and/or stage boundaries (Webby, 1998) and investigations are now underway to identify sections that have the necessary attibutes to serve as global stratotype section and point (GSSP) for these boundaries. One such level is the base of the Nemagraptus gracilis Graptolite Biozone, with this horizon defined, following the recommendation by Finney and Bergström (1986), as the level of first appearance of the zonal index. After careful consideration of several alternative levels, this was approved by the ISOS as the base of the Upper Ordovician Series (Webby, 1998). The base of the Nemagraptus gracilis Biozone is well defined by the first appearance of the zonal index. In key sections, this follows slightly after the disappearance of its direct ancestor, $N$. subtilis (Finney, 1985). In addition, this stratigraphic interval includes the radiation of early species of Dicellograptus (e.g. D. geniculatus, D. vagus, and D. gurleyi) and Dicranograptus (e.g. D. irregularis). Also, the first appearance of $N$. gracilis is a short stratigraphic interval above the boundary between the Pygodus serra and Pygodus anserinus Conodont Biozones, the eponymous species of which also represent ancestor/descendent species.

A world-wide review shows that there is only a small number of stratigraphically continuous sections with good graptolite and other fossil control across this biozonal boundary. A considerable number of sections have good Nemagraptus gracilis Biozone faunas but in most of these, the base of the biozone is not exposed, or is somewhere within an interval without diagnostic graptolites, or is marked by an unconformity. Our initial search for a suitable GSSP section resulted in the selection of four stratotype candidates, three of which have been visited and restudied by three of us (SMB, SCF, CX) and one (Fågelsång) visited and restudied by four of us (SMB, SCF, YG, $\mathrm{CP}$ ). These sections are situated at Calera, State of Alabama, southeastern USA, Dawangou, Xinjiang Autonomous Region, western- 


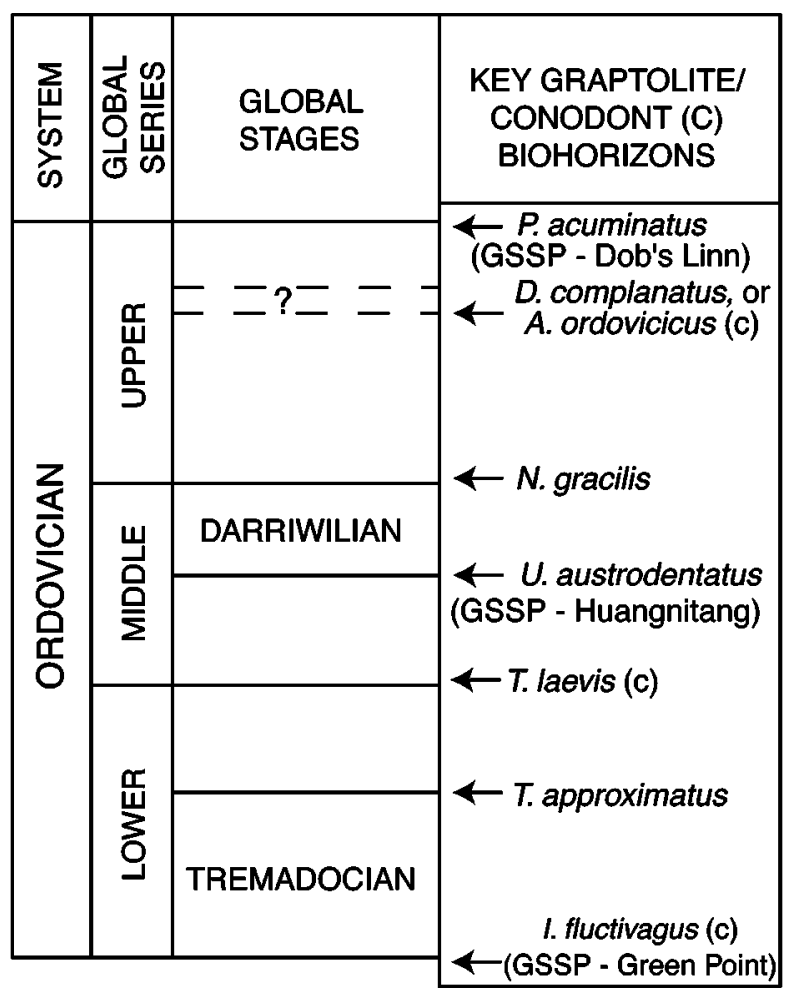

Figure 1 Diagram showing stratigraphic location of biohorizons approved by the International Subcommision on Ordovician Stratigraphy as defining the base of global Ordovician stages and series.

most China, Pingliang, Gansu Province, north-central China, and Fågelsång, southern Sweden. The pros and cons of these sections have been discussed in recent publications (Bergström and others, 1998, 1999a; Finney and others, 1999) and at international meetings in Madrid, Spain (1998), Prague, Czech Republic (1999), and Denver, Colorado (1999). A revision of the Pingliang section graptolite biostratigraphy showed that it does not extend down to the base of the Nemagraptus gracilis Biozone (Finney and others, 1999) and hence it is unsuitable as a stratotype for this biozone level. The full potential of the Fågelsång section as a GSSP was not recognized until its graptolite biostratigraphy near the base of the Nemagraptus gracilis Biozone was revised in the early summer of 1999. Because the completion and publication of our detailed investigations of the Fågelsång section will necessarily require considerable time, we judge it appropriate to now present to the geological community a summary of the key data at hand which bears on the suitability of this section as a GSSP.

\section{The Fågelsång section}

\section{Location, geologic setting, and lithology}

The proposed stratotype is within four closely spaced natural outcrops (by Moberg (1910) referred to as E14a, E14b, E14c, and E15) along the south bank of the Sularp Brook at Fågelsång, $8 \mathrm{~km}$ east of the center of the City of Lund (Figures 2 and 3). Fågelsång is located about $20 \mathrm{~km}$ north of the major international airport at Sturup, and is served by a busline from Lund. The outcrops are easily accessible by walking 200-300 $\mathrm{m}$ across the fields southward from Highway $9411.5 \mathrm{~km}$ west of Södra Sandby. A slightly longer but perhaps more convenient alternative route is a public footpath that runs northward from a parking area adjacent to the highway at the Fågelsång settlement. This footpath follows the west side of the Rögle Brook (also known as the Fågelsång Brook) and continues westward along the south bank of the Sularp Brook just above the outcrops. The locality is within a nature preserve but there are no access and scientific sampling restrictions. Judging from published descriptions, the natural outcrops have not changed substantially for more than a century and because of their location, they are highly unlikely to be affected in the foreseeable future by dumping, road or house building, or other human destructive activities.

The Fågelsång region is a classical Ordovician outcrop area in Baltoscandia. Geological investigations of its approximately $145 \mathrm{~m}$ thick, richly fossiliferous, Ordovician succession have been carried out at least since the early 1700's (Regnell, 1991; also see Moberg, 1910). Fågelsång is the type locality of the zonal index Hustedograptus teretiusculus (Hisinger) and the first illustrated description of Nemagraptus gracilis (Hall) from this area is by Törnquist (1865). A monograph by Hadding (1913) includes descriptions and illustrations of the herein proposed stratotype outcrops, their faunas, and their graptolite biostratigraphy. More recent important work dealing with the portion of the Ordovician of concern here includes the descriptions of two drill-cores, the Fågelsång drill-core (Hede, 1951) and the Koängen drill-core (Nilsson, 1977), and revision of Hadding's (1913) conodonts (Lindström, 1955). Bergström and Nilsson (1974) described the graptolite and conodont biostratigraphy of the outcrops and its relations to the sequence in the Koängen drill-core, and Finney and Bergström (1986), and Bergström and others (1998) briefly reviewed the graptolite and conodont biostratigraphy. Some information about the outcrops are also provided in several field trip guides (for instance, Regnell, 1960; Bergström, 1982) and by Ahlberg (1992).

Like coeval sequences elsewhere in Scania, the Fågelsång Ordovician succession is condensed but remarkably complete stratigraphically. It is dominated by fine clastic rocks deposited in an outer shelf or foreland basin setting not far from the southern margin of the Baltic plate (Bergström and others, 1999b). For detailed descriptions of the lithology of the stratigraphic interval of concern here, see Hede (1951) and Nilsson (1977). Aspects of the many Kbentonite beds in the Fågelsång region have been dealt with by Bergström and Nilsson (1974) and Bergström and others (1995, 1997). Although mainly consisting of dark-gray shale and mudstone, the interval encompassing the base of the Nemagraptus gracilis Biozone also contains some other rock types, including several carbonate concretions, some of which have a diameter of more than $0.5 \mathrm{~m}$. Furthermore, about $1.4 \mathrm{~m}$ above the base of the Nemagraptus gracilis Biozone, there is an approximately $0.15 \mathrm{~m}$ thick, partly conglomeratic and pyritic, bed of phosphorite which serves as an excellent stratigraphic marker bed in both cores and outcrops in the Fågelsång region. For convenient reference, it is here named the 'Fågelsång Phosphorite'. Another phosphoritic layer, no more than 1 $\mathrm{mm}$ thick but rich in conodonts and other microfossils, is located about $6.5 \mathrm{~m}$ below the Fågelsång Phosphorite. This layer, which is best accessible but not readily found, at about the $4.2 \mathrm{~m}$ level above the base of the E15 outcrop, is also present at the base of the E14c locality and is the source of most of the conodonts described by Hadding (1913) and later revised by Lindström (1955). It is herein informally referred to as the 'Hadding's conodont bed'. Another important non-clastic unit is a $2-3 \mathrm{~cm}$ thick layer of gray, partly conglomeratic, fine-grained limestone located a few $\mathrm{cm}$ below the Fågelsång Phosphorite that has produced a diverse conodont fauna. These beds are very useful for lithologic correlation between the outcrops and the drill-cores in the Fågelsång region (Figure 2).

The strata investigated were certainly deposited well below storm base, probably at a water depth exceeding $100 \mathrm{~m}$. The striking similarity between the successions in the drill-cores and the outcrops indicates a remarkably uniform deposition across a several $\mathrm{km}$ wide area. Subsequently, the strata have been affected by minor faulting causing a south-west dip of 2-4 degrees but otherwise not affecting the succession in the key outcrops. Because the conodonts in the limestone bed just below the Fågelsång Phosphorite have a Color Alteration Index of 5, which indicates a heating of about 300 degrees C (Bergström, 1980), these rocks are probably unsuitable for magnetostratigraphic studies. No chemostratigraphic investigations have yet been performed on these strata. The several K-bentonite beds 


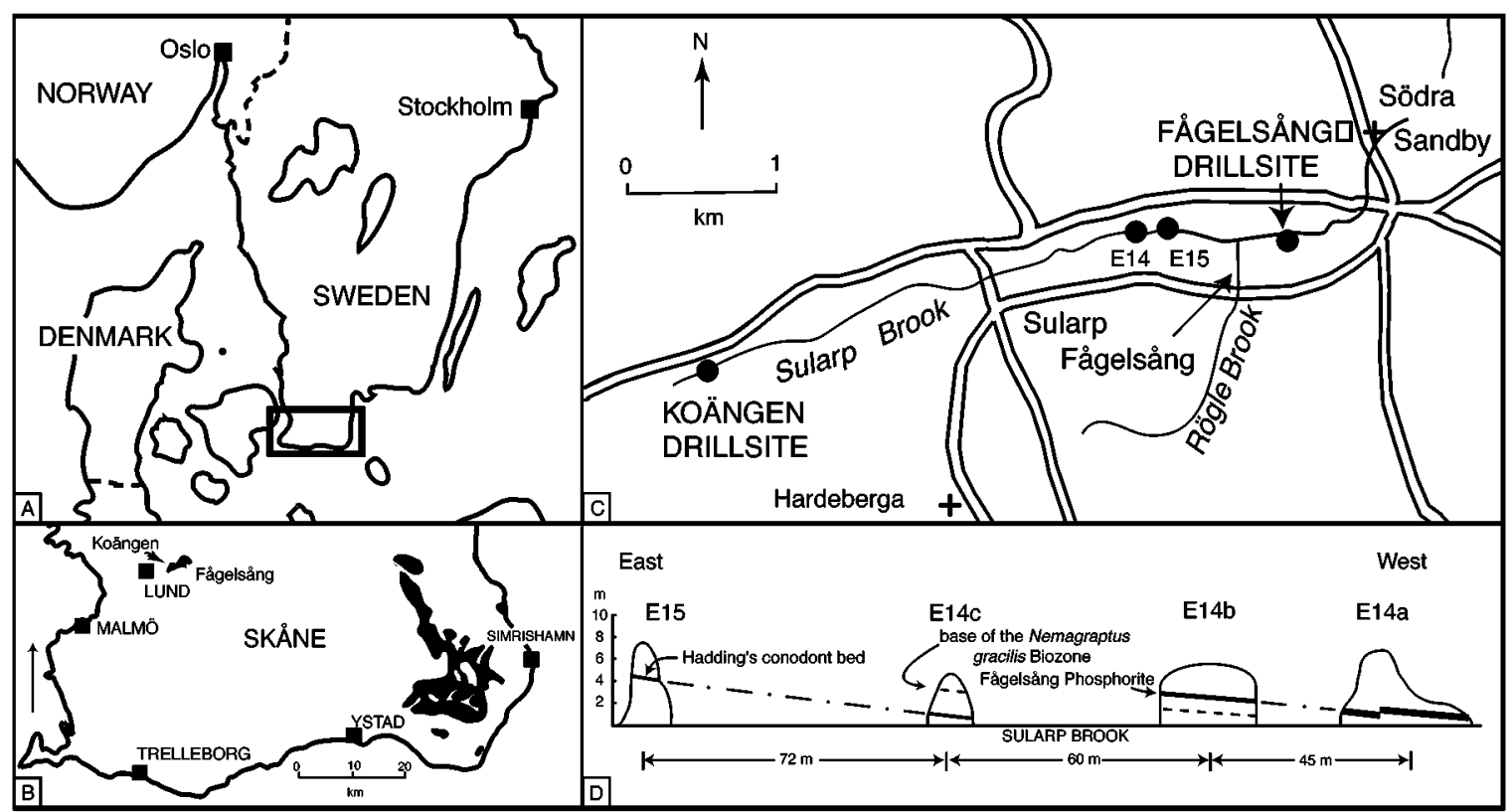

Figure 2 Location of the proposed stratotype section at Fågelsång, southern Sweden. A and B, orientation maps of southernmost Sweden. Black areas in B illustrate Ordovician outcrops areas; C, map of the Fågelsång area showing location of the E14 and E15 outcrops and the drillsites; D, schematic figure showing relations between the E14 and E15 sections along the south bank of the Sularp Brook. Note the position of the base of the Nemagraptus gracilis Biozone (broken line), the Fågelsaing Phosphorite (broken by a small fault in the E14a section), and Hadding's conodont bed. These levels are very useful for precise correlation between the Fågelsång sections.

present in the Nemagraptus gracilis Biozone in the outcrops and the Koängen drill-core (Bergström and Nilsson, 1974; Nilsson, 1977) have potential for isotopic dating but attempts to find dateable minerals have not yet been successful.

It is important to note that the base of the Nemagraptus gracilis Biozone is within an interval of vertically uniform lithology and there is no lithologic evidence of any stratigraphic break. That con-

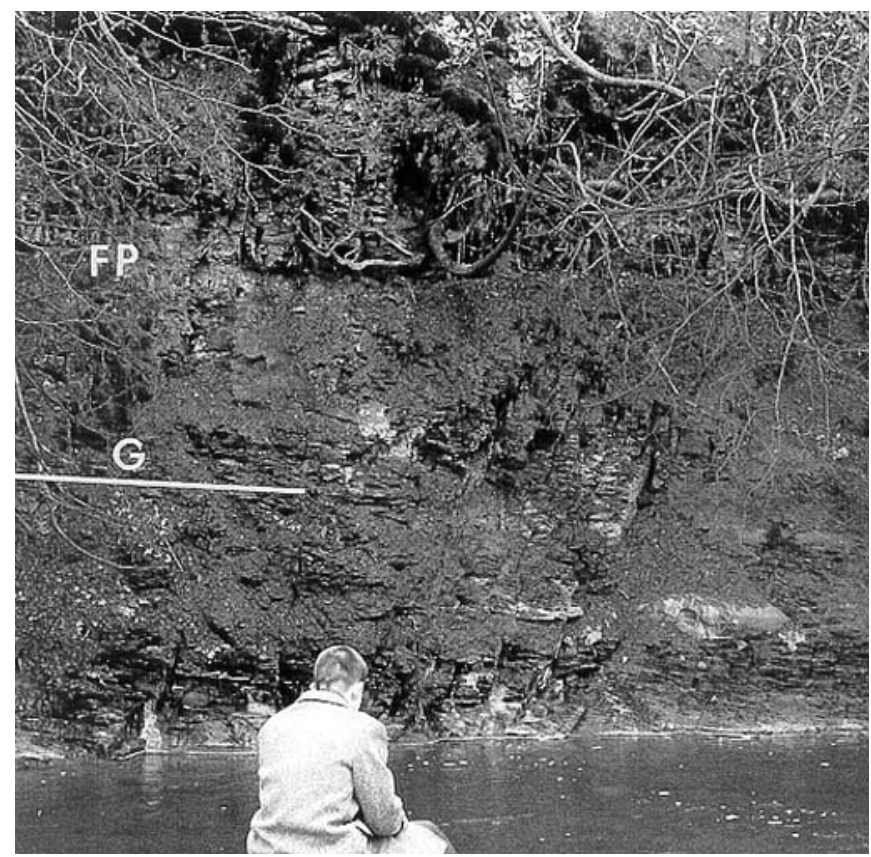

Figure 3 Photograph of part of the E14b outcrop along the Sularp Brook. This outcrop is proposed as the GSSP of the base of the Upper Ordovician Series. The level of the base of the Nemagraptus gracilis Biozone is marked by the white G line. FP marks the Fågelsång Phosphorite. The photograph was taken during spring flood---during most of the year, there is little water in the brook and the section is easily accessible for study. tinued deposition prevailed across this level is also indicated by the vertical distribution of graptolite species (Figure 4). As noted by Finney and Bergström (1986), the Fågelsång Phosphorite about 1.4 $\mathrm{m}$ above the biozone boundary is likely to represent a period of very slow, or possibly at times even interrupted deposition, but comparison with the conodont succession in sections elsewhere in Sweden indicates that if there is a stratigraphic break at that level, it is of very minor magnitude and encompassing only a portion of a conodont subzone, and only a part of the middle Nemagraptus gracilis Biozone. Likewise, there is no biostratigraphic or other evidence that the Hadding's conodont bed represents an even minor stratigraphic gap.

\section{Graptolite biostratigraphy}

The base of the Nemagraptus gracilis Biozone is located within a fine-clastic succession that traditionally has been referred to as the Dicellograptus Shale (Törnquist, 1889). Being basically a chronostratigraphically defined unit, this designation is obviously inappropriate in a modern lithostratigraphic classification but it is kept for the purpose of the present contribution. The fauna of the Dicellograptus Shale is dominated by graptolites, conodonts, chitinozoans, ostracodes, and inarticulate brachiopods but there are also sporadic occurrences of shelly macrofossils (Hede, 1951; Lindström, 1954; Nilsson, 1977). Graptolites are common and well-preserved in the Nemagraptus gracilis Biozone and the underlying Hustedograptus teretiusculus Biozone. Hence Hede (1951) listed about 25 species from the interval of the Fågelsång drill-core here included in the Nemagraptus gracilis Biozone and Nilsson (1977) recorded more than 40 species from the same interval in the Koängen drillcore. These are among the taxonomically most diverse graptolite faunas recorded anywhere in the world from this stratigraphic interval and they are useful for precise world-wide correlations.

During the course of the present study, the very large and carefully labeled graptolite collections from the Fågelsång (Hede, 1951) and Koängen (Nilsson, 1977) drill-cores, both housed at the Department of Geology, Lund University, were reexamined by SCF. This material was supplemented by reexamination of Hadding's (1913) specimens from the outcrop sections as well as recent outcrop collections made and identified by CP. A general summary of the distribution of important graptolite species is given in Figure 4. 


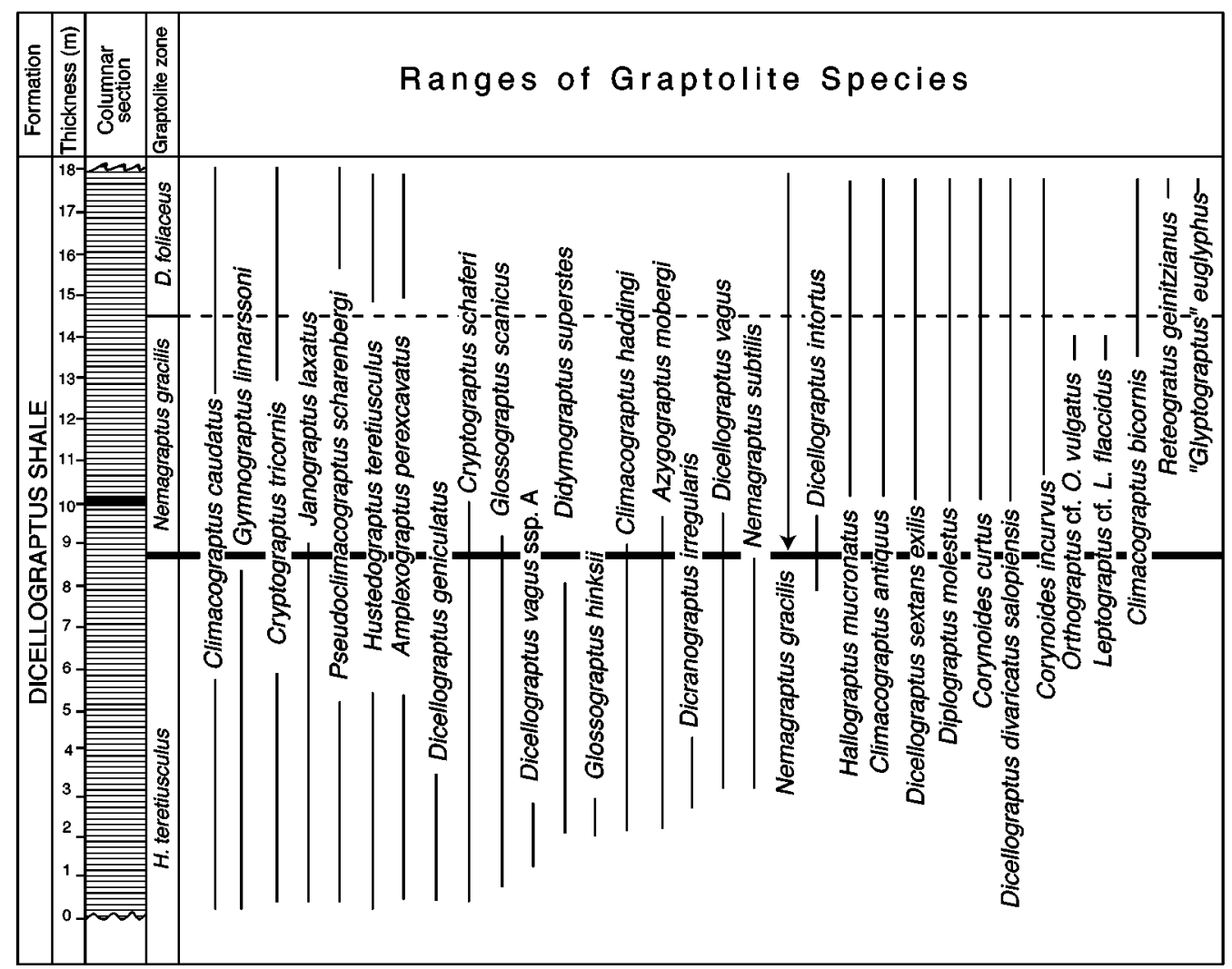

E14b
Figure 4 Stratigraphic ranges of important graptolites in the Hustedograptus teretiusculus, Nemagraptus gracilis, and lowermost Diplograptus foliaceus (formerly D. multidens) Biozones in the Fågelsaing area. Ranges shown are based on Hede (1951), Nilsson (1977), and recent reinvestigations by us. Note the position of the base of the Nemagraptus gracilis Biozone about $1.4 \mathrm{~m}$ below the Faigelsaing Phosphorite (black bed just above the 10 m level).

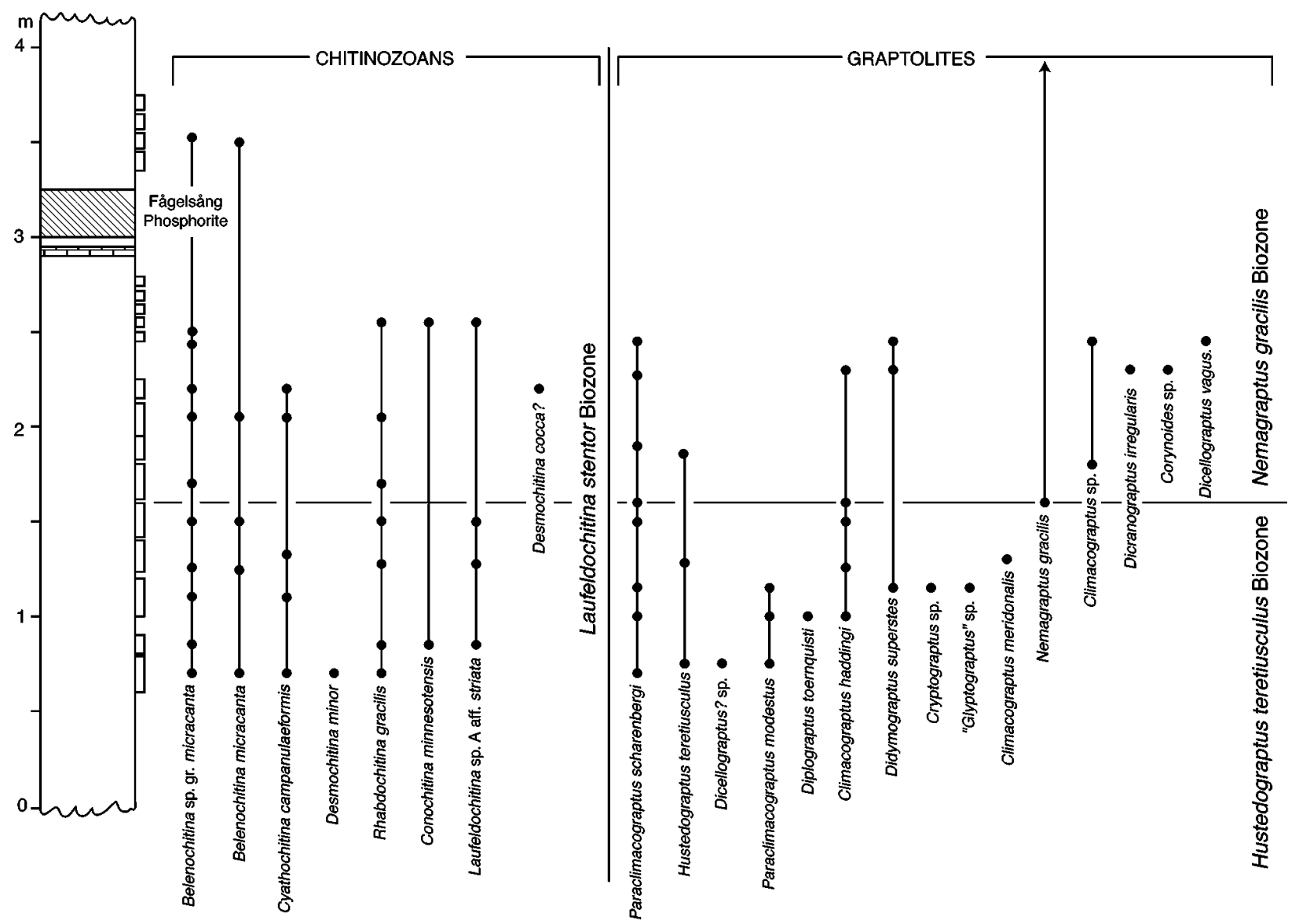

Figure 5 Stratigraphic ranges of graptolites and chitinozoans across the base of the Nemagraptus gracilis Biozone at the E14b outcrop based on recent collections. Chitinozoan and graptolite identifications by YG and CP, respectively. Position of chitinozoan samples marked by open boxes along the right side of the stratigraphic column. Note that the successions of these fossils provide no evidence of any stratigraphic break in the interval near the base of the Nemagraptus gracilis Biozone. 


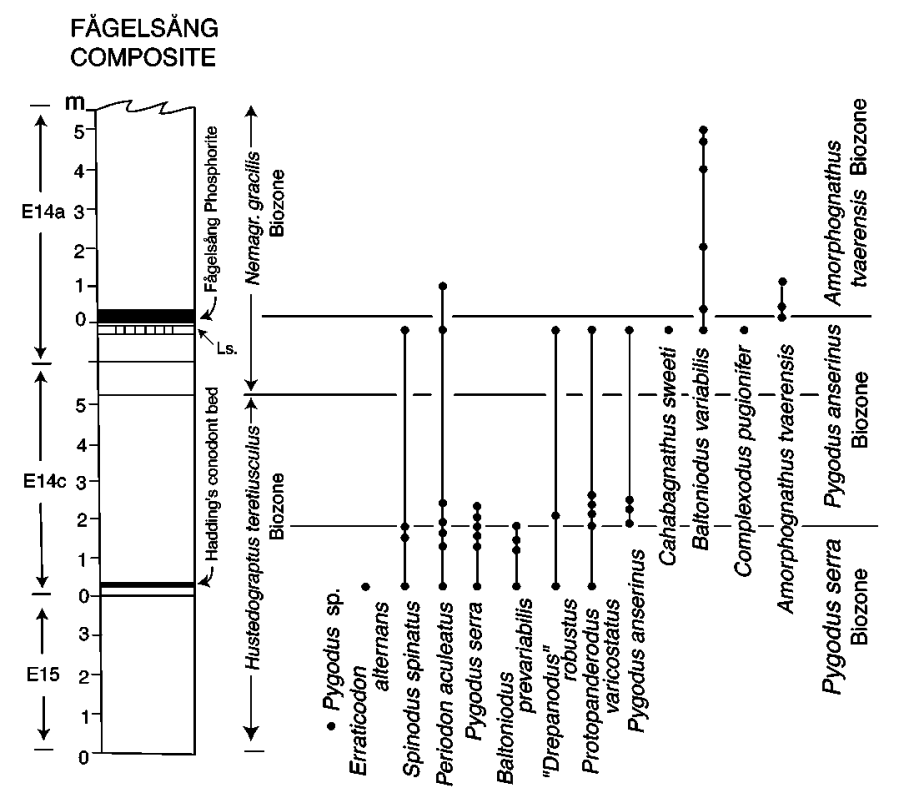

Figure 6 Stratigraphic ranges of important conodonts in the Fågelsaing succession, based on the E14a, E14c, and E15 outcrops. Note that the Pygodus serra/Pygodus anserinus Biozone boundary is about $3.5 \mathrm{~m}$ below the base of the Nemagraptus gracilis Biozone.

Traditionally, the base of the Nemagraptus gracilis Biozone was placed at the Fågelsång Phosphorite (Tullberg, 1883; Moberg, 1910; Hadding, 1913; Hede, 1951; Bergström and Nilsson, 1974; Nilsson, 1977). Recent study has confirmed Hadding's (1913, p. 17) long overlooked record of rare specimens of Nemagraptus gracilis also below this bed. Our restudy suggests that Nemagraptus gracilis first appears about $1.4 \mathrm{~m}$ below the Fågelsång Phosphorite at the E14b outcrop and at a closely similar level in the Fågelsång drillcore. This level is now taken as the base of the Nemagraptus gracilis Biozone. Interestingly, Nemagraptus subtilis, the likely ancestor of Nemagraptus gracilis, disappears at about the same level. That this horizon is otherwise not marked by a prominent turnover in the graptolite fauna is consistent with the interpretation that there is no stratigraphic gap in the succession at this level. An approximately $10 \mathrm{~m}$ thick succession below the Fågelsång Phosphorite contains a diverse graptolite species assemblage (Hadding, 1913; Hede, 1951), including, among others, early species of Nemagraptus, Dicellograptus, and Dicranograptus along with Gymnograptus linnarssoni, Glossograptus scanicus, and Climacograptus haddingi. This interval was formerly classified into four (Tullberg, 1882), three (Moberg, 1910), or two (Hadding, 1913; Hede, 1951) graptolite biozones. However, the suggestion by Jaanusson and Strachan (1955) that this interval should be referred to as the Glyptograptus (now Hustedograptus) teretiusculus Biozone has been followed by subsequent authors. Although the present revision of the base of the Nemagraptus gracilis Biozone restricts the size of the Hustedograptus teretiusculus Biozone by about $15 \%$, the zonal assemblage of the restricted zone remains characteristic.

Apart from being displayed in the Fågelsång drill-core (Hede, 1951), the base of the Nemagraptus gracilis Biozone is well exposed in the uppermost portion the E14c outcrop and the lower part of the E14b section (Figures 3, 5), which is located about $60 \mathrm{~m}$ from the E14c outcrop. The locality E14c is also important in displaying the interval across the base of the Pygodus anserinus Biozone (Figure 6). Nilsson's (1977) collections from the basal 3.5 m of the Koängen drill-core contain no specimens of Nemagraptus gracilis and there is currently no firm evidence, although it seems likely based on regional correlation, that this drilling penetrated below the level of the revised base of the Nemagraptus gracilis Biozone (Figure 7).

\section{Conodont biostratigraphy}

World-wide investigations during the last few decades have firmly established conodonts as key index fossils for local and global detailed correlations, and biozonal schemes have been developed throughout the Ordovician System. For the present contribution, we use the biozone classification introduced by Bergström $(1971,1983)$. The Fågelsång conodont biostratigraphy is mainly based on collections made by SMB during 1958-1968 supplemented by recently investigated drill-core specimens. Scattered and well-preserved conodonts occur on many shale bedding-planes, both in the drill-cores and in the outcrops, but substantial numbers of specimens have been obtained only from two levels (Figure 6), both situated in the outcrops, namely Hadding's conodont bed at the E15 outcrop and the thin limestone just beneath the Fågelsång Phosphorite at the E14a and E14b sections. The former unit has yielded a relatively diverse conodont fauna typical of the Pygodus serra Biozone, including numerous specimens of the zonal index, whereas the many specimens isolated from the thin limestone bed represent the upper part of the Pygodus anserinus Biozone. This species association is closely comparable to that present 3-5 m above the base of the Dalby Limestone (and the base of the Kukrusean Stage) in the limestone sections of south-central Sweden (Bergström, 1971) and provides support for Jaanusson and Strachan's (1955) suggestion that the base of the Nemagraptus gracilis Biozone is approximately coeval with the base of the Kukrusean Stage. This is also consistent with Regnell's (1948) record of Nemagraptus gracilis from the lowermost Dalby Limestone of northern Öland.

The stratigraphically lowest specimens of Pygodus anserinus, taken to mark the base of the Pygodus anserinus Biozone, have been collected from 200-210 cm above the base of the E14c exposure; this horizon is approximately $5 \mathrm{~m}$ below the Fågelsång Phosphorite and $3.5 \mathrm{~m}$ below the base of the Nemagraptus gracilis Biozone. This distribution pattern is consistent with that in the Fågelsång drill-core where the stratigraphically lowest specimens of Pygodus anserinus have been found at a core depth of 13.25-13.35 m and elements of Pygodus serra are present between 14.10-14.20 m (Figure 7). Regrettably, no Pygodus elements have yet been discovered in the $0.75 \mathrm{~m}$ thick core interval between these occurrences. Numerous specimens of Pygodus anserinus occur in the lowermost $0.5 \mathrm{~m}$ of the Koängen drill-core indicating that it does not reach into the Pygodus serra Biozone which is in good agreement with the graptolite evidence. Elements of Amorphognathus tvaerensis and other species of the Baltoniodus variabilis Biosubzone of the Amorphognathus tvaerensis Biozone occur on shale bedding planes a few $\mathrm{cm}$ above the Fågelsång Phosphorite (Figure 6). We conclude that not only has it been possible to establish a detailed conodont biostratigraphy, which is useful for global correlation, through the critical interval in the Fågelsång succession but also, the relations between the conodont and graptolite biostratigraphy are the same as in key sections elsewhere in the world.

\section{Chitinozoan biostratigraphy}

Chitinozoans have proved to be very useful in Baltoscandic Ordovician biostratigraphy (Nolvak and Grahn, 1993) and their occurrence in the E14b outcrop was studied by means of 18 closely spaced samples across the base of the Nemagraptus gracilis Biozone (Figure 5). The preservation of most specimens is rather poor and the species association is not very diagnostic biostratigraphically. Of special interest is the presence of Laufeldochitina sp. A aff. striata because typical specimens of this species are characteristic of the middle part of the Laufeldochitina stentor Chitinozoan Biozone (Nolvak and Grahn, 1993). Based on this and the conodont/chitinozoan zone correlations proposed by these authors (p. 249), it appears that the base of the Nemagraptus gracilis Biozone corresponds to a level near the middle of this chitinozoan biozone. 


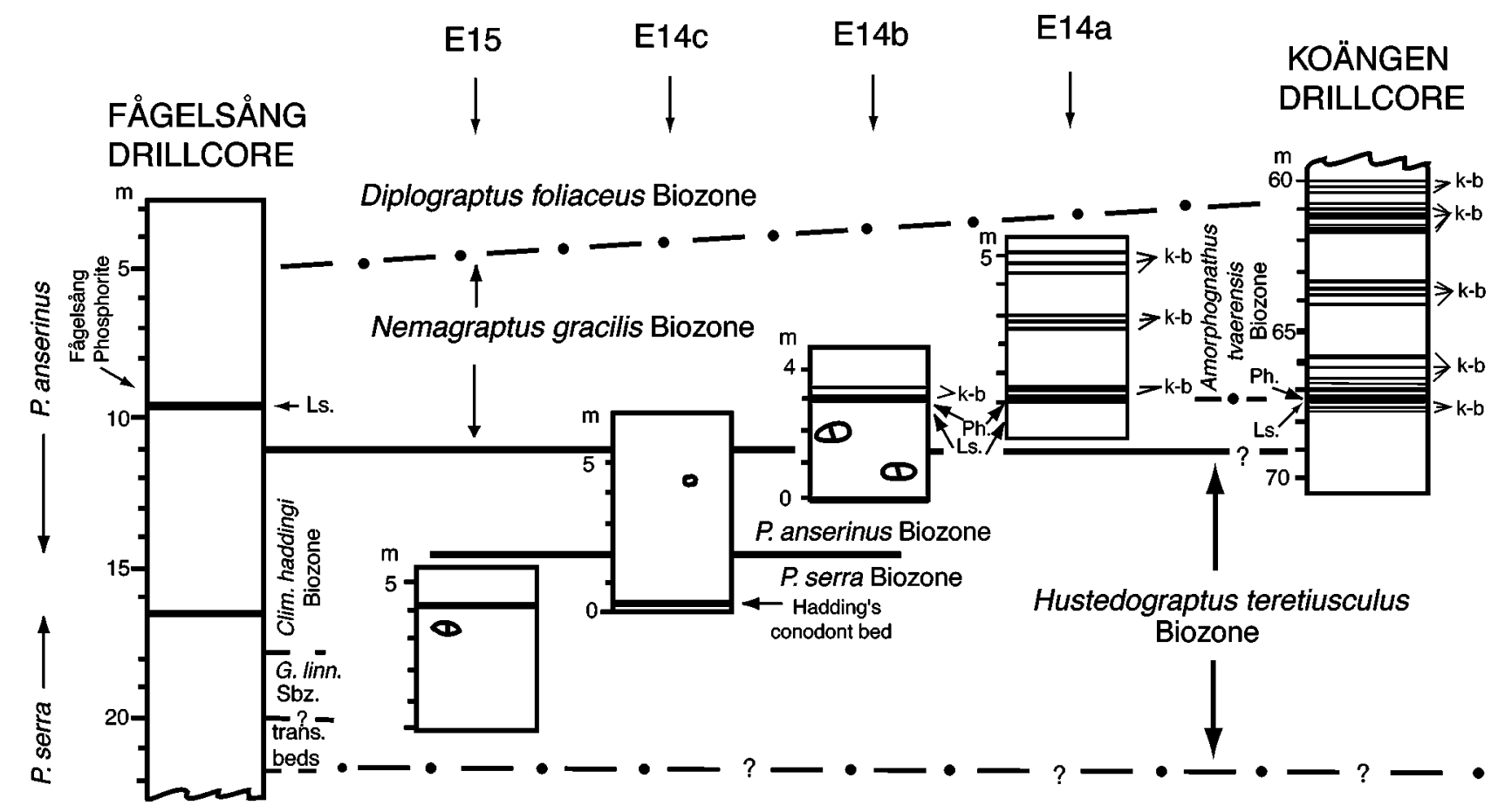

Figure 7 Relations between outcrops, drill-cores, and biozone boundaries in the Fågelsång area. K-b, K-bentonite; Ph, Fågelsång Phosphorite; ls., limestone just below phosphorite bed.

\section{Other sections}

As shown in a global review of sections representing the Nemagraptus gracilis Biozone (Finney and Bergström, 1986), there are very few localities that in terms of continuous succession, exposure, and biostratigraphic control are adequate enough to be considered as potential GSSP candidates. This is shown by the fact that there is no section in the United Kingdom that fulfills these requirement, including the ones in Wales recently restudied by R. Bettley, Oxford (personal communication 1998). Elsewhere in Europe, there is no suitable section and no good boundary section is known from Australia, eastern Russia, and Africa. Finney and others (1996) described several boundary sections in the southern and central Appalachians of eastern North America among which that at Calera (Finney, 1984) is by far the superior one. None of the localities reported from other parts of eastern North America, also including those on Newfoundland recently dealt with by Williams (1995), fulfill the requirements of a GSSP, and the same is the case with the sections in west Texas (Berry, 1960) and Arkansas. Likewise, we have not been able to identify any suitable stratotype candidate sections in Alaska, the Great Basin, and other parts of western and northern North America. Two sections not discussed by Finney and Bergström (1986) are that at Cerro Viejo, near Jachal, in the central San Juan Province of the Argentine Precordillera (Ortega and others, 1996; Ottone and others, 1999) and that in the Dawangou Gorge, Tarim, Zinjiang Autonomous Region, westernmost China (Bergström and others, 1999).

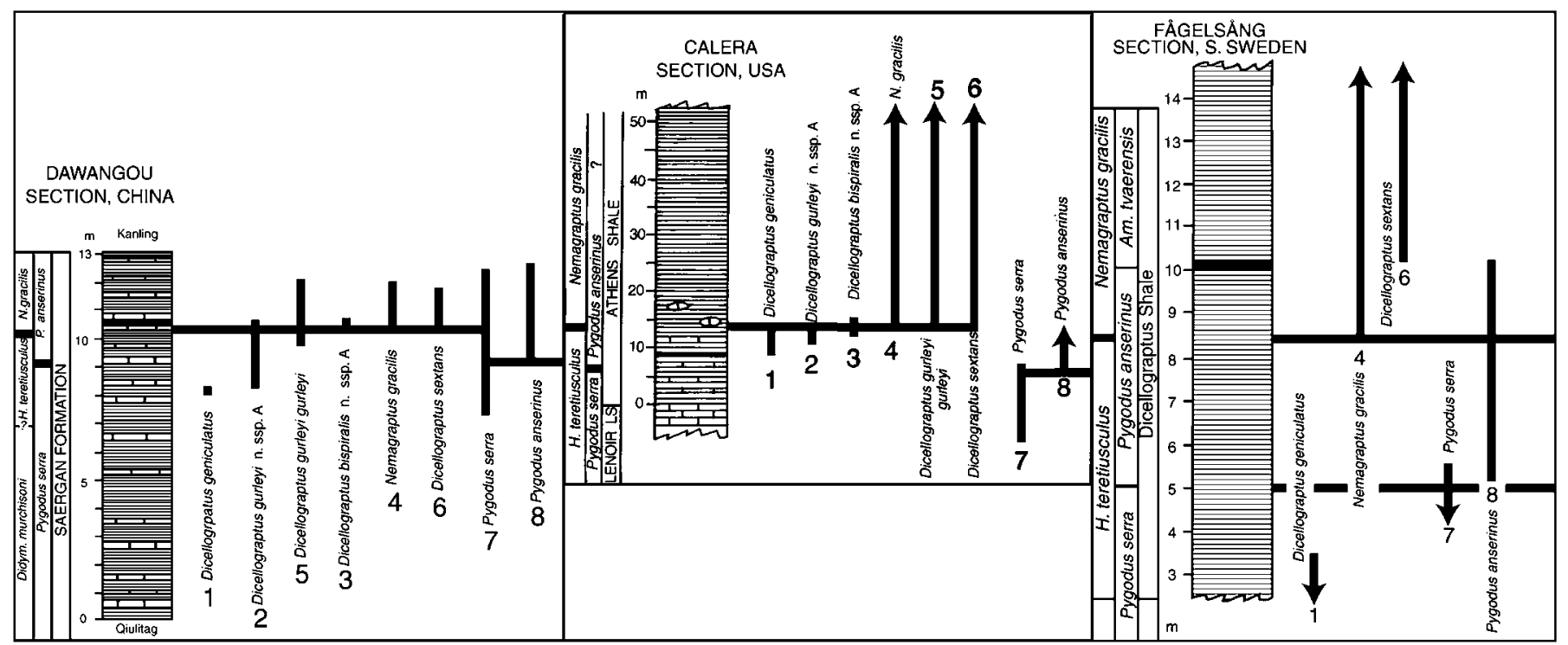

Figure 8 Comparison between the ranges of key graptolites and conodonts in the interval near the base of the Nemagraptus gracilis Biozone in the Dawangou, Calera, and Fågelsång successions. Note the similarity in ranges of fossil species, and in the relations between the base of the Nemagraptus gracilis Biozone and that of the Pygodus anserinus Biozone. 
The former is an excellent and extensive hillside outcrop of the Los Azules Formation with a continuous exposure of a graptolite sequence from the Paraglossograptus tentaculatus Biozone to the the upper Nemagraptus gracilis Biozone (Climacograptus bicornis Biosubzone). However, the succession appears to have a stratigraphic gap corresponding to the lower Nemagraptus gracilis Biozone (Ottone and others, 1999), and the absence of carbonate beds in most of the lithologically monotonous succession of gray shales in the Hustedograptus teretiusculus and Nemagraptus gracilis Biozones will make it difficult to establish a detailed conodont biostratigraphy.

The graptolite and conodont biostratigraphy of the wellexposed and stratigraphically continous Dawangou section has recently been revised (Bergström and others, 1999a). The Saergan Formation dark shales in that section contain a taxonomically diverse and typical Nemagraptus gracilis fauna that is closely similar to that at Calera. Conodonts from calcareous interbeds prove that the interval immediately below the level of appearance of Nemagraptus gracilis is coeval with the Hustedograptus teretiusculus Biozone but the moderately diverse graptolite fauna in that interval is not very distinctive. Nevertheless, this section is doubtless one of the best Nemagraptus gracilis Biozone boundary sections known anywhere in the world.

Based on a general assessment of how the GSSP requirements are fulfilled by the various boundary sections investigated, we conclude that there are now only three serious candidate sections, namely those at Fågelsång, Calera, and Dawangou. The latter two have been described recently (Bergström and others, 1998, 1999a) and we refer to those papers for details. It is interesting, and important, to note that that the appearance of key graptolite and conodont species, as well as the general graptolite-conodont biostratigraphy, are closely similar in these sections and in the Fågelsång one and all three sections can be precisely correlated with each other (Figure 8). The Calera section is superb because of its extensive fresh exposure and abundance of graptolites in the boundary interval. Conodonts are common on shale bedding surfaces and the section includes a K-bentonite bed. However, it is in a very active quarry and therefore constantly changing. Although access is currently granted by the quarry operators, we have some concern that this section will not be accessible indefinitely, and it may be destroyed by quarrying, or the quarry may be filled with water, or serve as a dump in the future. Being situated in a natural gorge at a considerable distance from human settlements, the Dawangou section does not have these problems and it has obvious appeal as a GSSP candidate but it has the drawback of being very remotely located. The Fågelsång E14b section fulfills most requirements of a GSSP and because we consider it to be the overall best among these three sections, we propose it as the stratotype section for the base of the global Upper Ordovician Series. Also, we propose the Dawangou and Calera sections as auxiliary stratotype sections for the same chronostratigraphic level.

\section{Conclusions}

The result of our world-wide assessment of suitable stratotype sections for the GSSP of the base of the global Upper Ordovician Series is that the Fågelsång section in southern Sweden is the best available one for the selected boundary level, the base of the Nemagraptus gracilis Biozone. This horizon, which represents the level of first appearance of Nemagraptus gracilis, is about $1.4 \mathrm{~m}$ below the the Fågelsång Phosphorite marker bed in the Dicellograptus Shale. Two closely spaced natural outcrops (E14b and E14c) provide good exposure of the boundary, and the recommended stratotype section is the E14b outcrop. Along with the E14c section, two carefully studied drill-cores from the Fågelsång area, which have lithological and faunal successions that are virtually identical to those at the outcrops, provide additional significant biostratigraphic information.

The boundary level is within a several tens of $m$ thick succession of dominantly dark-gray shales and mudstones representing an outer shelf or foreland basin depositional environment. There is no evidence of a lithologic or faunal break, or debris flows, at or near the biozone boundary, and the succession represents continuous deposition in a stable environment, possibly at a considerable water depth. The proposed stratotype, which is located near major cities and an international airport, is easily accessible in a natural creek bank exposure in a nature preserve, and it is very unlikely that it will be affected in the future by road or house construction or by other human destructive activities. Diverse graptolite, conodont, and chitinozoan faunas provide excellent biostratigraphic control, and these fossils can be used for precise global correlations of the biozone boundary in both shaly and shelly facies. The section has been thermally affected by thick overburden and/or intrusive dikes and hence, it is probably unfit for magnetostratigraphic work, but it has potential for chemostratigraphy as well as for isotopic datings of minerals present in the several K-bentonite beds in the Nemagraptus gracilis Biozone. The excellent Dawangou, China and Calera, USA sections, both of which can be closely correlated with the Fågelsång one, are proposed as auxiliary stratotype sections.

\section{Acknowledgements}

The present research has been supported by grants from the National Science Foundation (EAR-9004559 and 9205981), the National Geographic Society, and the Chinese Academy of Sciences. We are indebted to P. Ahlberg and R. Bettley for valuable information, to S. Laufeld for assistance with samples, and to B.Webby for a useful review of the manuscript.

\section{References}

Ahlberg, P., 1992, Fågelsångsdalen - ett klassiskt exkursionsområde: Lunds Geologiska Fältklubb 1892-1992, pp. 27-37. Schmidts Boktryckeri, Helsingborg.

Bergström, J., 1982, Scania. VI International Symposium on the Ordovician System, Field Excursion Guide: Palaeontological Contributions, University of Oslo, v. 279, pp. 184-197.

Bergström, S. M., 1971, Conodont biostratigraphy of the Middle and Upper Ordovician of Europe and eastern North America: Geological Society of America Memoir 127, pp. 83-161.

Bergström, S. M., 1980, Conodonts as paleotemperature tools in Ordovician rocks of the Caledonides and adjacent areas in Scandinavia and the British Isles: Geologiska Föreningens i Stockholm Förhandlingar, v. 102, pp. 377-392.

Bergström, S. M., 1983, Biogeography, evolutionary relationships, and biostratigraphic significance of Ordovician platform conodonts: Fossils and Strata, v. 156, pp. 35-58.

Bergström, S. M., Finney, S. C., Chen Xu, and Wang Zhi-hao, 1998, The base of the Nemagraptus gracilis Zone as the base of the global Upper Ordovician Series: Three potential stratotypes: Sixth International Graptolite Conference and 1998 Field Meeting, IUGS Subcommission on Silurian Stratigraphy, Temas Geologico-Mineros ITGE, v. 23, pp. 148-151.

Bergström, S. M., Finney, S. C., Chen Xu, and Wang Zhi-hao, 1999a, The Dawangou section, Tarim Basin (Xinjiang Autonomous Region), China: Potential as global stratotype for the base of the Nemagraptus gracilis Biozone and the base of the global Upper Ordovician Series: Acta Universitatis Carolinae-Geologica 1999, v. 43, pp. 69-71.

Bergström, S. M., Huff, W. D., Kolata, D. R., and Bauert, H., 1995, Nomenclature, stratigraphy, chemical fingerprinting, and areal distribution of some Middle Ordovician K-bentonites in Baltoscandia: GFF, v. 117, pp. $1-13$.

Bergström, S. M., Huff, W. D., Kolata, D. R., Yost, D. A. and Hart, C., 1997, A unique Middle Ordovician K-bentonite bed succession at Röstånga, Sweden: GFF, v. 119, pp. 231-244.

Bergström, S. M., Huff, W. D., Koren', T., Larsson, K., Ahlberg, P., and Kolata, D. R., 1999b, The 1997 core drilling through Ordovician and Silurian strata at Röstånga, S. Sweden: Preliminary stratigraphic assessment and regional comparison: GFF, v. 121, pp. 127-135.

Bergström, S. M. and Nilsson, R., 1974, Age and correlation of the Middle Ordovician bentonites on Bornholm: Bulletin of the Geological Society of Denmark, v. 23, pp. 27-48. 
Berry, W. B. N., 1960, Graptolite faunas of the Marathon region, Texas: University of Texas Publication 6005, pp. 1-179.

Finney, S. C., 1984, Biogeography of Ordovician graptolites in the southern Appalachians: Palaeontological Contributions, University of Oslo, v. 295, pp. 167-176.

Finney, S. C., 1985, Nemagraptid graptolites from Middle Ordovician Athens Shale, Alabama: Journal of Paleontology, v. 59, pp. 1100-1137.

Finney, S. C. and Bergström, S. M., 1986, Biostratigraphy of the Ordovician Nemagraptus gracilis Zone, in Hughes, C. P. and Rickards, R. B., (eds), Palaeoecology and biostratigraphy of graptolites: Geological Society Special Publication no. 20, pp. 47-59.

Finney, S. C., Bergström, S. M., Chen Xu, and Wang Zhi-hao, 1999, The Pingliang section, Gansu Province, China: Potential as global stratotype for the base of the Nemagraptus gracilis Biozone and the base of the global Upper Ordovician Series: Acta Universitatis Carolinae-Geologica 1999, v. 43, pp. 73-75.

Finney, S. C., Grubb, B. J., and Hatcher, R. D., Jr., 1996, Graphic correlation of Middle Ordovician graptolite shale, southern Appalachians: An approach for examining the subsidence and migration of a Taconic foreland basin: Geological Society of America Bulletin, v. 108, pp. 355-371.

Hadding, A., 1913, Undre Dicellograptusskiffern i Skåne: Lunds Universitets Årsskrift, N.F. v. 9(15), pp. 1-91.

Hede, J. E., 1951, Boring through Middle Ordovician-Upper Cambrian strata in the Fågelsång district, Scania (Sweden). 1. Succession encountered in the boring: Lunds Universitets Årsskrift, N.F. v. 46(7), pp. 1-78.

Jaanusson, V. and Strachan, I., 1955, Correlation of the Scandinavian Middle Ordovician: Geologiska Föreningens i Stockholm Förhandlingar, v. 76, pp. 684-696.

Lindström, M., 1955, The conodonts described by A. R. Hadding, 1913: Journal of Paleontology, v. 29, pp. 105-111.

Mitchell, C. E., Chen Xu, Bergström, S. M., Zhang Yuan-dong, Wang Zhihao, Webby, B. D. and Finney, S. C., 1997, Definition of a global boundary stratotype for the Darriwilian Stage of the Ordovician System: Episodes, v. 20, pp. 158-166.

Moberg, J. C., 1910, Guide for the principal Silurian districts of Scania. Geologiska Föreningens i Stockholm Förhandlingar, v. 32, pp. 45-194.

Nilsson, R., 1977, A boring through Middle and Upper Ordovician strata at Koängen in western Scania, southern Sweden: Sveriges Geologiska Undersökning, C733, pp. 1-58.

Nolvak, J. and Grahn, Y., 1993, Ordovician chitinozoan zones from Baltoscandia: Review of Palaeobotany and Palynology, v. 79, pp. 245-269.

Ortega, G., Albanesi, G. L., Ottone, E. G. and Holfelz, G. D., 1996, Conodonts, palynomorphs and graptolites from the Los Azules Formation, Argentine Precordillera: Sixth International Conodont Symposium (ECOS VI), Warszawa 1996, Abstracts, p. 44.

Ottone, E. G., Albanesi, G. L, Ortega, G. and Holfeltz, G. D., 1999, Palynomorphs, conodonts and associated graptolites from the Ordovician Los Azules Formation, Central Precordillera, Argentina: Micropaleontology, v. 45 , pp. $225-250$

Regnell, G., 1948, An outline of the succession and migration of non-crinoid pelmatozoan faunas in the Lower Palaeozoic of Scandinavia: Arkiv för Kemi, Mineralogi och Geologi, v. 26A, pp. 1-55.

Regnell, G., 1960, The Lower Palaeozoic of Scania, in Regnell, G. and Hede, J. E., The Lower Palaeozoic of Scania, The Silurian of Gotland, Guide to Excursions Nos A 22 and C 17: International Geological Congress, 21st Session, Guide-books, pp. 1-43.

Regnell, G., 1991, Sven Nilsson (1787-1883) on graptolites: Geologiska Föreningens i Stockholm Förhandlingar, v. 113, pp. 25-33.

Törnqvist, S. L., 1865, Om Fågelsångstraktens undersiluriska lager. Geologiska iakttagelser: Lunds Universitets Årsskrift, v. 1 (II:3), pp. 1-24.

Törnquist, S. L., 1889, Några anmärkningar om vestra Europas kambriska och siluriska kronologi. Geologiska Föreningens i Stockholm Förhandlingar, v. 11, pp. 299-339.

Tullberg, S., 1982, Skånes graptoliter. I. Sveriges Geologiska Undersökning, C50, pp. 1-44.

Webby, B. D., 1994, Steps towards establishing globally applicable boundaries for the Ordovician System: major international divisions and criteria for definitions: Ordovician News, v. 11, pp. 6-15.

Webby, B. D., 1995, Towards an Ordovician time scale: 7th International Symposium on the Ordovician System, Society of Sedimentary Geology, Pacific Section, Book 77, pp 5-9.

Webby, B. D., 1998, Steps toward a global standard for Ordovician stratigraphy: Newsletters on Stratigraphy, v. 36, pp. 1-33.

Williams, S. H., 1995, Middle Ordovician graptolites from the Lawrence Harbour Formation, central Newfoundland, Canada: Palaeontographica, Abt. A, v. 235, pp. 21-77.
Stig M. Bergström is Professor of Geological Sciences at the Ohio State University, USA where he has been teaching since 1968 after having received his graduate traning at Lund University, Sweden. He has been a voting member of the International Subcommission on Ordovician Stratigraphy since 1974 and served as subcommission secretary in 1976-1982. His principal research interest is global Ordovician geology, especially aspects of the evolution of the Iapetus, the significance of Lower Paleozoic K-bentonites, and conodont and graptolite morphology and biostratigraphy.

Chen $\mathbf{X u}$, born in 1936, graduated from the Beijing College of Geology in 1959, employed by the Nanjing Institute of Geology and Paleontology, Academia Sinica from 1959 to present. Research Professor from 1989, Vice-Chairman of the International Subcommission on Ordovician Stratigraphy from 1991. Main research interests are Ordovician and Silurian stratigraphy and graptolites.

Stanley C. Finney is Chair and Professor in the Department of Geological Sciences at California State University at Long Beach. Research interests include graptolite biostratigraphy and paleoecology. He was recently elected 2nd Vice Chair of the International Commission on Stratigraphy for the terms 20002004, and he is Chair of the Subcommission on Ordovician Stratigraphy for two term (19962004).
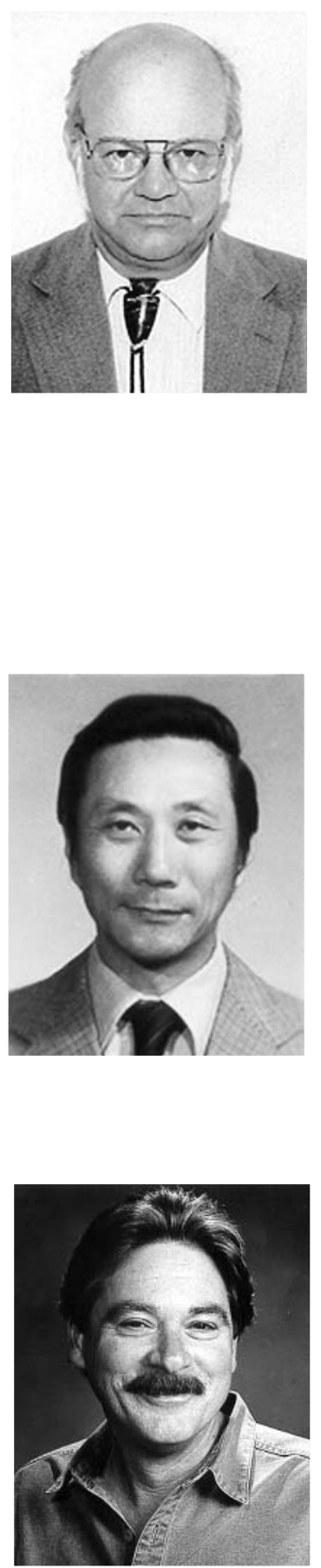